\title{
Fight or freeze? Individual differences in investors' motivational systems and trading in experimental asset markets
}

\begin{abstract}
We analyze investors' trading behavior, particularly their coping with fundamental shocks in asset value, depending on individual differences in the sensitivity of two basic neurophysiological systems-the Behavioral Approach System (BAS), the 'driving force' of human behavior, and the Behavioral Inhibition System (BIS), its 'braking system'. By analyzing 15 independent experimental asset markets with a total of 171 participants, we find that differences in BAS and BIS sensitivity affect trading in both 'normal' and shock-trading environments: under normal trading conditions, individuals with a more sensitive BAS are more active traders, prefer riskier portfolios, and generate higher individual overall profits. High BIS subjects generate lower scalping and overall profits. Fundamental shocks generally reinforce the preference of high BAS investors for riskier portfolios, while positive shocks 'unfreeze' high BIS investors: they trade more frequently and generate higher profits. At the market level, normal trading in markets with a high BIS median is associated with lower volatility, compared to low BIS median markets, while greater concentration of traders' BAS scores around the mean is associated with better efficiency and liquidity, compared to markets with lower BAS kurtosis. In high BIS median markets, positive shocks lead to improved efficiency, lower bid-ask spread, and lower volatility. We observe no significant differences in market-level reactions to negative shocks.
\end{abstract}

JEL classification: C91; G02; G11; D03; D81.

PsycINFO classification: $3100 ; 3600$.

Keywords: Individual decision making; Investment decisions; Behavioral Approach System/Behavioral Inhibition System; Experimental asset markets; Fundamental shocks.

\section{Word count: 10,450}




\section{Introduction}

Field and laboratory studies have reported deviations from the proposition that prices reflect fundamental values, and adjust quickly and correctly to new information about changes in this value (e.g., Bloomfield et al., 2009). The empirical evidence is reflected in behavioral models of market over- or underreaction and momentum (e.g., Barberis et al., 1998; Daniel et al., 1998). These behavioral explanations argue that cognitive biases provide reasons as to why anomalies characterize financial market behavior (Ackert and Deaves, 2010; Stracca, 2004). Beyond documenting the existence of biases, scholars have, however, also uncovered substantial heterogeneity across individuals — in their susceptibility to biases (e.g., Chen et al., 2007; Da Costa et al., 2006; Fenton-O’Creevy et al., 2005); trading styles (e.g., Barber and Odean, 2001; Deaves et al., 2009); and trading performance (e.g., Oliven and Rietz, 2004; Smith et al., 1988). ${ }^{1}$

While demographic and socioeconomic variables appear to play a role (e.g., Ackert and Church, 2001; Dhar and Zhu, 2006; Fellner and Maciejovsky, 2007; Forbes and Kara, 2010; Loibl and Hira, 2009; McInish and Srivastava, 1984; Powell and Ansic, 1997; Sachse, et al., 2012), a considerable part of this variation remains unexplained. A nascent literature, hence, advances differences in personality as a complementary explanation. Scholars have studied the influence of personality traits such as locus-of-control (Chui, 2001; Fenton-O’Creevy et al., 2005; McInish, 1980, 1982), self-monitoring (Biais et al., 2005), sensation seeking (Grinblatt and Keloharju, 2009), chronic self-regulatory focus (Liu, 2011), and the 'Big Five’ (Fenton-O’Creevy et al., 2005), on individuals' trading and investment. Yet, important questions remain unanswered. For example, other studies suggest that the impact of individual traits may be too limited to prominently and generally explain variations in trading (e.g., Lo et al., 2005).

This study, therefore, analyzes the impact of two fundamental motivational systems that are central to theories of personality psychology (Brenner et al., 2005) and rooted in human neurophysiology — the Behavioral Approach System (BAS) and the Behavioral Inhibition System (BIS)

\footnotetext{
${ }^{1}$ We use the terms 'investor' and 'trader' interchangeably to refer to individuals who trade for their own accounts.
} 
(Fowles, 1980, 1993; Gray, 1982, 1987). Despite their fundamental nature, no study has, to date, analyzed their influence on financial decision making. To the best of our knowledge, only three studies have examined their impact on economic decision making, and all of them did so in different task environments (gambling tasks) (Van Honk et al., 2002; Franken and Muris, 2005; Kim and Lee, 2011). Scholars argue that much of human behavior is driven by these two systems, and that individuals differ in the sensitivity of their BAS and BIS to environmental signals of reward and punishment (Carver and White, 1994; Depue and Iacono 1989; Fowles, 1980, 1993; Gray, 1982, 1987). Together, they are at the heart of interpersonal differences in appetitive motivation (BAS), i.e. the tendency to move towards something pleasant, and aversive motivation (BIS), i.e. the tendency to move away from the threat of something unpleasant.

Specifically, the BAS stimulates activities in response to reward signals (e.g., anticipation of a monetary reward). It activates approach behaviors, has been referred to as the 'engine' or 'driving force' of human behavior, and is neurophysiologically associated with the motor programming system (Gray, 1994). High BAS sensitivity appears to be linked to traits such as impulsivity (Gray, 1994), and novelty seeking (Cloninger, 1987), to states such as positive affect (Watson et al., 1999) and energetic arousal (Thayer, 1986), and has been associated with a tendency to engage in goal-directed efforts (Caver and White, 1994): faced with the prospect of obtaining a desired outcome, high BAS individuals will 'fight more vigorously in order to get it.

The second system-BIS—governs aversive motivation and is neurophysiologically associated with the septohippocampal system (Depue and Iacono, 1989; Gray, 1994). Its function is to halt ongoing behavior while processing potential threat signals (Gray, 1982, 1987). It responds to signals of punishment, non-reward, and novelty by increasing attention, and by halting behavior that may have negative consequences. The BIS stimulates withdrawal from or avoidance of behaviors that may have adverse implications; high BIS activation is associated with increased attention, vigilance and anxiety (e.g., Fowles, 1988; Quay, 1988). Therefore, BIS activation is argued to block movement towards goals (Carver and White, 1994). The BIS has 
been linked to avoidant and inhibitory traits such as anxiety and neuroticism (Gray, 1994), and to states such as negative affect (Gray, 1994). Generally, higher BIS sensitivity appears to be related to proneness to anxiety and reduced goal-directed efforts (Caver and White, 1994): faced with the prospect of a potentially negative outcome, high BIS individuals are more likely to 'freeze'.

This paper takes an explorative approach to shed first light on the impact of BAS/BIS on trading. We hypothesize that individual differences in BAS/BIS sensitivity influence investors' behavior in general, and their coping with fundamental shocks- - defined as sudden changes in the expected value of a (risky) asset due to new information-in particular. Specifically, we expect that high BIS individuals focus more on the potential negative consequences ('threat signals') of holding risky assets, whereas high BAS traders emphasize the potential upside ('reward signals'). A looming shock is likely to reinforce these tendencies. Therefore, this study addresses two research questions. First, under 'normal' trading conditions, how do individual differences in BAS/BIS sensitivity affect individual trading behavior and outcomes (e.g., profits and frequency), and how does market composition with respect to BAS/BIS affect market performance (efficiency, liquidity, and volatility)? Second, how do individual- and market-level reactions to fundamental shocks differ depending on differences in BAS/BIS sensitivity?

We investigate these questions in an asset market experiment with 171 subjects. Our analyses reveal, first, that individual trading behavior and outcomes as well as market performance under normal trading conditions are significantly affected by differences in BAS/BIS sensitivity. High BAS individuals hold riskier portfolios with higher numbers of shares, trade more frequently, including trading for the purpose of scalping, and generate higher profits. High BIS individuals generate lower scalping and overall trading profits. At the market level, high BIS median is associated with lower volatility, compared to low BIS median markets, while greater concentration of traders' BAS scores around the mean is related to better efficiency and liquidity, compared to markets with lower BAS kurtosis. Second, reactions to fundamental shocks are also affected by differences in BAS/BIS sensitivity, especially at the individual level. Both 
types of shocks reinforce high BAS traders' preference for riskier portfolios and they engage even more frequently in (scalping) trades. Following negative (but not positive) shocks, high BAS individuals underreact strongly. High BIS traders 'unfreeze' in response to positive shocks: they trade more frequently and generate higher profits. Negative shocks do not alter their behavior significantly. In high BIS median markets, positive shocks lead to improved efficiency, lower bidask spread, and lower volatility. We do not observe any significant market-level effects in response to negative shocks.

\section{Experimental Design and Procedure}

\subsection{Participants}

171 subjects from various fields of study, 112 females (mean age $=21.49$; sd=2.39) and 59 males (mean age $=21.17$; $\mathrm{sd}=2.39$ ), participated. They received performance-dependent monetary rewards (for details, see section 2.3 Procedure).

\subsection{Design}

We used a computerized experimental market programmed in z-tree (Fischbacher, 2007). The basic setup was similar to previous market experiments (e.g., Fellner and Maciejovsky, 2007; Gneezy et al., 2003; Weber and Welfens, 2007). Participants could sequentially trade multiple units of a risky single-period asset in a continuous open-book double auction market in a sequence of twelve four-minute trading periods. At the beginning of each period, a trader was endowed with 1,330 units of an experimental currency ('ECUs') and five units of the risky asset. There was one type of risky asset. At the end of each period, each unit of the asset was a lottery ticket worth a certain amount of money. The exact value ('dividend') was state-dependent. At the beginning of each round, four states—A, B, C, and D-were possible, equally likely, and independent from previous rounds. If at the end of a period state A applied, each unit of the asset was worth 0 ECUs. B, C, and D resulted in values of 100, 300, and 400 ECUs. The state that applied to a round was determined by a computerized random draw after trading had ended. A message on the computer screens revealed the realized draw. Subsequently, the next period 
started. As in Gneezy et al. (2003) and Weber and Welfens (2007), all subjects had the same information and were fully informed about all possible states and probabilities.

Traders could submit bids to buy and orders to sell at any time during a trading period. All traders were instantaneously informed about all submitted bids and orders. When a unit was traded, the accepted bid or order was withdrawn from the market, and all traders were informed that a trade had occurred at that price. All bids and orders were for one unit only. In each period, if a trader bought (sold) a unit, the price was subtracted from (added to) her cash balance, and one unit of the asset was added to (subtracted from) her portfolio. A trader's earnings for the period were equal to: $1,330+$ [prices received for units sold] - [prices paid for units bought] + [number of units in portfolio at the end of the period] $\mathrm{x}$ [value of the asset as determined by the lottery draw]. At the beginning of the next period, all portfolios were re-initialized. Traders could not use accumulated earnings from earlier rounds and were not allowed to go short in either assets or cash. An individual improvement rule was enforced.

During each session, we administered two trading treatments to the same participants (within-subject design). In treatment 1 (T1; NORM), trading continued uninterrupted for four minutes. In treatment 2 (T2; SHOCK), during each four-minute interval, trading was interrupted after two minutes and subjects were confronted with an exogenous shock in the form of new information about the value of the asset. Out of the initially possible four states, we randomly eliminated either the two low-payout states A and B (positive/high shock), or the two highpayout states C and D (negative/low shock). Both types of shocks were equally likely. Following a shock, all outstanding bids and orders were cancelled, and trading continued for another two minutes. ${ }^{2}$ Endowments were not re-initialized after a shock, but at the beginning of the next

\footnotetext{
2 In deleting all outstanding bids and asks after each shock, we follow the design of Weber and Welfens (2007). While retaining outstanding bids and asks would constitute a more realistic alternative design option, we opted for following the design by Weber and Welfens (2007) for two main reasons. First, it allows for controlling for idiosyncratic lengths and depths of order books at the market level, and for identifying characteristic momentum patterns. Second, not clearing the order book would have 'automatically' induced an additional amount of underreaction. For example, a trader who had posted a limit order indicating her willingness to buy the asset at a price of 200 just prior to a negative shock would indeed have been forced to purchase it from the first seller quick enough to accept the outstanding bid after the low shock. Even if the first trader would have tried to enter an
} 
four-minutes trading period. ${ }^{3}$ In the instructions for T2, participants were informed about the occurrence of a shock, but not whether it would be positive or negative.

\subsection{Procedure}

The experiment was conducted in the ELSE lab at Utrecht University, the Netherlands, with a total of 15 sessions; 15 subjects per session-225, in total—were recruited by announcements and were asked to fill in an online questionnaire two weeks in advance to collect data on psychometric measures and investment experience, of which 204 subjects (13.6 students per session) filled in the questionnaire. Of these, 171 subjects (between 8-15 students per session with an average of 11.4) showed up in the lab two weeks later. We matched the data from the survey and the experiment using a unique, random computer-generated identifier to ensure anonymity. No subject was allowed to participate more than once and upon entering the lab, subjects were randomly seated behind PCs.

Following the two trading treatments, an additional set of three treatments was run in order to assess loss aversion (T3; Rabin (2000), Gächter et al. (2007); separately incentivized), risk aversion (T4; Holt and Laury (2002); separately incentivized), and overconfidence (T5; similar to

Biais et al. (2005)), which are used as control variables, but are not analyzed separately here.

Because they were always played last, we expect no confounding effects on the results reported here. ${ }^{4}$ Subjects only received information about the immediately imminent treatment. ${ }^{5}$ After the first set of instructions was distributed, subjects traded during two practice periods in which no feedback was provided. After a clear break, actual trading started. At the end of each session, each participant learned about her payoff via a message on her computer screen, and was paid

\footnotetext{
improved (in this case, lower) price in response to the shock, it is likely that this would have taken her longer than it would have taken the (lucky) seller to simply click on 'accept' to secure the previous bid of 200. The resulting trade would have looked like underreaction on the part of the buyer, although the buyer was perfectly aware of the implications of the shock and would have entered a much lower bid price for a new limit order. The design implemented in this study, therefore, represents a more conservative scenario for assessing underreaction and allows us to investigate in a more controlled manner the 'pure' treatment effect on individuals' underreaction.

3 The described experimental design builds on the standard assumption that individuals derive utility from monetary gains. Note, though, that we do not assume a particular shape of the utility function.

${ }^{4}$ We do not report overconfidence in the results here, because it never showed any significant effect. When included (in unreported robustness checks; available upon request from the authors), it does not alter our results qualitatively. ${ }^{5}$ Upon request, the complete set of instructions and the experimental data are available from the authors.
} 
her earnings in private. Total experimental earnings consisted of payoffs from trading, and the payoffs from T3 and T4. All three components of total earnings were independent of each other. A subject's trading profit was based on one randomly chosen period, for which her earnings were calculated according to the aforementioned formula. The exchange rate was 0.008 , resulting in an expected payoff from trading of $€ 18.64$. The average realized payoff per subject was $€ 18.16$ $(\mathrm{sd}=7.48 ; \min =.18 ; \max =39.38)$. The overall average payoff (including T3 and T4) was $€ 26.95$ $(\mathrm{sd}=8.06 ; \min =5.03 ; \max =49.23)$. On average, the experiment took approximately 120 minutes.

\section{Methods}

We separately analyze the following 'market types': (i) normal trading (T1; NORM), (ii) pre-shock trading (T2; sub-treatment: T2-PRE), and post-shock trading, divided into (iii) high shock (T2; sub-treatment: T2-POST HI), and (iv) low shock (T2; sub-treatment: T2-POST LO). Each of these market types was administered in each session with a different market composition (group of traders). We henceforth refer to a combination of composition and market type as 'market'.

\subsection{Individual-Level Variables}

The following dependent variables are defined at the subject-period level of observation. Number of stocks and Trading frequency capture trading strategies. Number of stocks refers to the absolute number of stocks in a subject's portfolio (i) at the end of each period of 240 seconds of normal trading, (ii) at the end of each interval of 120 seconds of pre-shock trading, (iii) at the end of 120 seconds of trading after a positive shock, and (iv) at the end of 120 seconds of trading after a negative shock. If this number is greater (smaller) than five, a trader was a net buyer (seller) of stocks with a correspondingly higher (lower) risk exposure than at the start of the period. Trading frequency is measured as the absolute number of trades a subject was involved in during a period.

Trading profits, Scalping profits, Scalping frequency, and Underreaction assess trading performance. Trading profits are measured as an individual's total assets at the end of a period (cash and shares), with shares valued at their expected value prior to the realized lottery draw. Scalping profits capture performance when trading for the purpose of making profits from selling high and buying low 
(rather than potentially benefiting from a high dividend). They are measured as the average profit per stock $\Pi_{m, i}$ of trader $i$ in market $m$, benchmarked against the average price of a stock in the market (henceforth 'market price'). ${ }^{6}$

$$
\Pi_{m, i}=\frac{\sum_{s=1}^{S_{i}}\left(p_{s, i}-p_{m, i}\right)+\sum_{b=1}^{B_{i}}\left(p_{m, i}-p_{b, i}\right)}{S_{i}+B_{i}}
$$

For traders who did not sell or buy any stocks in a period, $\Pi_{m, i}=0$. Scalping frequency

assesses the frequency with which a trader trades for the purpose of buying and selling, rather than for the purpose of changing the number of stocks in her portfolio. It is measured as the minimum of all shares sold and all shares bought in a period. ${ }^{7}$ Underreaction assesses the degree to which a trader is (too) slow in adapting to a change in fundamental value. Analogously to Weber and Welfens (2007), and with $v_{t}$ representing the risk-neutral expected value of a stock ('fundamental value') ${ }^{8}$ during a specific trading period $t$, we compute underreaction $U_{i}$ as:

$$
U_{i}=\left\{\begin{array}{l}
\frac{\sum_{s=1}^{S_{i}}\left(v_{t}-p_{s, i}\right)}{S_{i}} \text { if } v_{t}=350 \\
\frac{\sum_{b=1}^{B_{i}}\left(p_{b, i}-v_{t}\right)}{B_{i}} \text { if } v_{t}=50
\end{array}\right.
$$

The greater $U_{i}$, the more trader $i$ underreacts. In contrast to Weber and Welfens (2007), who define underreaction with average trading prices at the market level, we measure underreaction at the individual level. This has two advantages. First, we can distinguish between buying and selling per individual, because only traders who sell (buy) below (above) the expected value after a high (low) shock underreact. The counterparties, in contrast, do not underreact, but,

\footnotetext{
${ }^{6}$ For example, if $S_{i}=2$, stocks are sold at $p_{s, i}=210$ (with s=1) and $p_{s, i}=205$ (with s=2) and $B_{i}=1$ stock is bought at $p_{b, i}=197$ (with $\mathrm{b}=1$ ), and $p_{m, i}$ equals 200 , then scalping generates $\Pi_{m, i}=(210-200+205-200+200-197) /(2+1)=6 \mathrm{ECU}$ per traded stock of trader $i$. In order to keep the market price independent from a subject's own trading prices, we exclude the latter and compute the market price $p_{m, i}$ by averaging the prices of all other traders in the market. ${ }^{7}$ For example, if a subject bought three stocks and sold four, the scalping frequency is three, the total trading frequency is seven, and the number of stocks (in the final portfolio) is four. The total trading frequency (Trading frequency; see above) is a combination of scalping frequency and the number of stocks. Total trading frequency is the sum of twice her scalping frequency plus the absolute difference between the initial and final number of stocks in her portfolio. In the example above, this is: $(2 * 3)+|(5-4)|=7$.

${ }^{8}$ The fundamental value of a stock in normal and pre-shock trading is 200 ECUs, 350 ECUs in high post-shock trading and 50 ECUs in low post-shock trading.
} 
by buying low/selling high, exploit opportunities opened up by underreacting traders. Second, market risk premiums do not bias our results. At the market level, post-shock trades below the new expected value may not indicate underreaction, but simply the risk premium of a risk-averse market. At the individual level, though, a specific trader may underreact even if the market, on average, does not. Hence, in comparing an individual's underreaction to the market's average, the market's risk premium is implicitly accounted for.

In order to compare trading before and after a shock, for each of the dependent variables (with the exception of Underreaction), we deduct an individual's pre-shock average from her corresponding post-shock average. The comparisons are measured separately for high and low post-shock trading. Per individual, all dependent variables are averaged per period, separately for normal, pre-shock, and high (low) post-shock trading. To account for differences in market composition, we follow prior literature (e.g., Lo et al., 2005) and mean-center and standardize all dependent variables at the market level. Thus, per individual and market type, we retain six observations, one per period-hence, $171 * 6=1,026$ observations in the normal and the pre-shock market type. Each of the two post-shock market types has fewer observations, because per period there was either a high or a low shock. Together they add up to $1,026 .{ }^{9}$

The independent variables, $B A S$ and $B I S$, are measured using the BIS/BAS scales by Carver and White (1994). The BIS scale is a seven-item, four-point Likert-type scale. BAS is measured using the BAS Reward Responsiveness (BAS-RR) sub-scale, which is a five-item, fourpoint Likert-type scale. In order to facilitate interpretation, we re-coded the scores such that a higher score implies higher sensitivity. Using confirmatory factor analyses, we established that the measurements are distinct. Further, to validate our measurements individually, we ran reliability tests and common factor analyses per scale. The largest factor in each measurement has an eigenvalue well above one (1.276 for BAS, and 2.470 for BIS). The difference to the eigenvalue

\footnotetext{
${ }^{9}$ As a robustness check, we also averaged all values per individual and market across all trading periods in a session, resulting in only 171 observations per market type (mean-centered and standardized per market). All results reported here remain qualitatively intact.
} 
of the second-largest factor is substantial so that the eigenvalue of the latter is much smaller (for BAS, the difference is 1.242; for BIS, the difference is 2.204). We therefore do not exclude any items from the original scales. BIS (BAS) has a Cronbach's $\alpha$ of .788 (.61). Both values exceed the critical threshold of 0.6 as defined by Bagozzi and Yi (1988). In line with Biais and Weber (2009), we focus on the deviations between subjects' characteristics within the group in which they traded. Analogously to the dependent variables, we mean-centered and standardized all independent variables at the market level..$^{10}$

\subsection{Market-Level Variables}

Informational efficiency assesses the degree to which market prices fully and correctly reflect all available information and thereby the true value of an underlying asset (Fama, 1970). We measure informational efficiency (Efficiency) as the root mean squared deviation of prices from the fully efficient true rational expectations price forecast (e.g., Theissen, 2000; Friedman, 1993). The root mean squared error (RMSE) measures the quality of information aggregation in a market. A lower RMSE indicates a more efficient market. The RMSE for a period is defined as:

$$
R M S E_{t}=\sqrt{\left[\frac{1}{n_{t}} \sum_{j=1}^{n_{t}}\left(p_{j, t}-v_{t}\right)^{2}\right]}
$$

The true asset value in period $t$ is denoted as $v_{t}$. The index $j$ characterizes the trading price during a specific period with $n_{t}$ representing the total number of trades by the end of period t. Market liquidity relates to the degree to which an asset can be (re-)sold without causing a significant movement in the market price and without losing value substantially. The bid-ask spread is a widespread measure of liquidity (Liquidity) in field markets, which has also been employed in experimental asset markets (e.g., Theissen, 2000). Following Theissen (2000), we measure the quoted bid-ask spread as the average spread (ask minus bid) of open limit orders in a trading period $t$. We also assess the volatility of prices (Volatility), which is a measure for the variation over time of prices for an asset. Generally, higher volatility implies a wider distribution

\footnotetext{
${ }^{10}$ All control variables, their measurements and sources are described in detail in Appendix A.
} 
of possible final portfolio values. Volatility is measured as the standard deviation of traded prices during a period $t$.

In exploring the effects of group (market) composition, we included a measure of (i) the average level and (ii) the heterogeneity of the attribute(s) of interest (e.g., Barrick, Stewart, Neubert, and Mount, 1998; Neuman, Wagner, and Christiansen, 1999). We assessed market composition with respect to BAS/BIS sensitivity using (i) the median of BAS and BIS scores (BAS median and BIS median) of all subjects in a market (session), ${ }^{11}$ and (ii) the kurtosis of the corresponding distributions ( $B A S$ kurtosis and BIS kurtosis), as it is concerned with the tails of the distribution (unlike, for example, the standard deviation). ${ }^{12}$

\section{Results}

\subsection{Descriptives}

Figure 1 shows the average trading price per second, its smoothed 95\% confidence interval, the number of limit orders in the system, and the number of trades executed (per eight seconds). In line with prior research, the average market price mostly lies below the fundamental value of 200 (e.g., Deaves et al., 2009), which suggests a risk-averse market.

\section{[INSERT FIGURE 1 ABOUT HERE]}

Figures 2 and 3 show the trading development in the shock treatments. Trading in the pre-shock phase is comparable to normal trading. In the post-shock phase, prices exhibit a characteristic momentum pattern as they drift towards the new fundamental value. ${ }^{13}$ After a high (low) shock, trading prices stay significantly below (above) the expected stock values for the first 22 (34) seconds, before they converge to the new fundamental levels. This observation is consistent with the idea that at least some subjects used the pre-shock price as an anchor (Kahneman and Tversky, 1973, 1974). With a value of 200 as an anchor, a post-shock selling price of 300 or a post-shock buying price of 100 look like a bargain, even though they are far

\footnotetext{
${ }^{11}$ The results are qualitatively robust but slightly weaker when using the mean.

12 The main results are qualitatively robust to the inclusion of the inter-quartile range instead of kurtosis.

${ }^{13}$ Note that this is not an order book effect, because we cleared the order book at the announcement of a shock.
} 
from their new fundamental values. Weber and Welfens (2007) found a similar momentum pattern, which they show to be caused by underreaction.

Prior research has shown that investors are 50 per cent more likely to sell stocks that are above their purchase value than stocks that show a loss (Odean, 1998). In our experiment, too, subjects sold their stocks for a gain much quicker than for a loss. After a positive shock, many stocks sold for prices between 250 and 300, thus for a gain of 25-50 per cent compared to preshock levels. After a negative shock, however, almost all trading was at prices below 100, where the stocks had lost more than 50 per cent. This asymmetry is consistent with loss aversion and the disposition effect (Kahneman and Tversky, 1979; Shefrin and Statman, 1985; Odean, 1998). ${ }^{14}$ Kirchler (2009) observes a similar asymmetry in mispricing between markets with increasing and decreasing fundamental values. ${ }^{15}$

Further, we observe changes in market risk attitude following the shocks. After a positive shock, most equilibrium prices were below the fundamental value: participants preferred to avoid risk. Following a negative shock, however, the average equilibrium price stayed exclusively above the fundamental value. The same participants now sought risk. This switch of risk attitudes from the gain to the loss domain is also consistent with prior studies (Kahneman and Tversky, 1979).

\section{[INSERT FIGURES 2 AND 3 ABOUT HERE]}

While there is some heterogeneity across sessions in terms of market size, trading frequency, and average market price, ${ }^{16}$ robustness checks show that our results are qualitatively robust to the deletion of outlier sessions (e.g., Session 14). This is in line with prior studies that have found that the size of experimental asset markets—-for example, beyond a threshold of approximately eight traders—does not influence trading behavior significantly (e.g., Fellner and

\footnotetext{
${ }^{14}$ Interestingly, similar effects related to loss realization aversion and processes of anchoring and adjustment have recently been reported for real estate markets (e.g., Einio et al., 2008; Genesove and Mayer, 2001).

${ }^{15}$ He reports that markets with bullish (i.e., above-average mean fundamental values) are characterized by a significantly lower absolute difference between prices and fundamental value compared to bearish markets (with a below-average mean fundamental values), implying that bullish markets exhibit a lower degree of underreaction.

${ }_{16}$ Table A2 in Appendix A2 reports the number of traders, the trading frequency, and the average market price per session. Because normal trading is twice as long as pre- or post-shock trading, trading frequencies are also approximately double as high. The average number of stocks is always five. It is therefore not reported in the table.
} 
Maciejovsky, 2007). Table 1 reports the pairwise correlations of all explanatory variables at the individual level (averaged across all periods of a session), together with the basic descriptives. ${ }^{17}$ No coefficient exceeds an absolute level of 0.36 (Age and Master_PhD). We test for multicollinearity by computing variance inflation factors (VIF). No independent variable exceeds a VIF-value of 1.52 , with a mean of 1.24 for all explanatory variables, both of which are well below the established thresholds of 5.3 (Hair et al., 2006) and 10 (Belsley et al., 1980;

Studenmund, 1992). Hence, multicollinearity is not a concern in this study.

\section{[INSERT TABLE 1 ABOUT HERE]}

We use multivariate OLS regression. To account for interdependences within markets (sessions), all standard errors are adjusted for heteroskedasticity using robust estimators of variance (Huber, 1967; White, 1980) that are clustered at the market (session) level for all individual-level (market-level) estimations. The results are qualitatively robust to the addition of session or period fixed effects. Joint parameter tests reveal, however, that session or period fixed effects do not add explanatory power to the specifications shown below. This can be attributed to the fact that the variables are standardized at the market level, which already corrects for unobserved effects at the session-period level. ${ }^{18}$

\subsection{T1-NORM Trading}

Table 2 reports results for individual-level analyses in the normal trading environment (T1-

NORM). First, investors with higher BAS sensitivity have a preference for riskier portfolios and are more active traders. They also trade more frequently for the purpose of scalping, and they generate higher overall trading profits. Second, higher BIS sensitivity is associated with significantly lower overall trading profits, and lower scalping profits.

[INSERT TABLES 2 AND 3ABOUT HERE]

\footnotetext{
17 The mean, standard deviation, minimum and maximum are reported for the unstandardized variables. We exclude the number of traders (market size) because it does not vary across individuals. When included, it shows no statistically significant pairwise correlation with any of the other variables reported.

${ }^{18}$ Due to space constraints, all results shown refer to full model specifications, which include all independent variables. When included separately, the effects remain qualitatively robust (available upon request from the authors).
} 
Table 3 reports regressions for the effects of market composition in terms of BIS/BAS sensitivity on market-level outcomes for NORM trading (T1-NORM). Higher median BIS sensitivity is associated with significantly lower volatility. Higher BAS kurtosis (i.e., more mass at the center and thinner tails) is associated with a lower bid-ask spread and marginally associated with higher efficiency. In interpreting these market-level results (see also Table 6), it is important to note that high BIS (median) does not imply low BAS (median). Instead, the comparison is between high and low (median) BIS, and between high and low (median) BAS.

\subsection{T2-SHOCK Trading}

Table 4 reports differences between pre- and post-high-shock trading. The number of observations is lower, because only 40 out of 90 periods with shock trading were exposed to a high shock. For underreaction to a positive shock, we require that a trader sells at least one stock after a positive shock in order to be able to assess whether or not she exhibits underreaction. This happened in 275 (of 455) subject-period observations. Analogously, Table 5 reports the results after a negative shock; 50 (out of 90) periods were exposed to a negative shock (571 subject-period observations). Of these, 368 observations record the purchase of at least one stock, allowing for the computation of underreaction. As Table 4 reveals, differences in both BAS and BIS sensitivity affect reactions to positive shocks at the individual level. Traders with a more sensitive BAS respond by restructuring their portfolios towards including more risky assets and by engaging more frequently in scalping, but fail to convert this into higher scalping profits. Subjects with higher BIS sensitivity react by trading more frequently. In the process, they generate significantly higher trading profits, compared to pre-shock trading. After a positive shock, neither higher BAS nor higher BIS sensitivity are associated with a stronger tendency towards underreaction. In contrast, Table 5 shows that differences in responses to negative shocks are driven solely by differences in BAS sensitivity. High BAS sensitivity traders react- 
again—by restructuring towards riskier portfolios. They trade more frequently relative to preshock trading, and strongly underreact. ${ }^{19}$ Differences in BIS sensitivity have no significant effect.

\section{[INSERT TABLES 4 AND 5 ABOUT HERE]}

Table 6 reports results for the effects of BIS/BAS market composition on market-level outcomes for post-shock trading following positive (Table 6; Panel (a); T2-POST-HI) and negative shocks (Table 6; Panel (b); T2-POST-LO). After a positive shock, a higher median BIS level is associated with lower bid-ask spread, greater informational efficiency, and reduced volatility, compared to pre-shock levels. After negative shocks, none of the individual coefficients is significant, neither is any of the market-model specifications (prob $>\mathrm{F}=.295$ or higher).

\section{[INSERT TABLE 6 ABOUT HERE]}

\section{General Discussion and Conclusion}

This study reports results of an asset market experiment to examine the impact of interpersonal differences in BAS/BIS sensitivity on trading behavior and performance. We analyzed trading under 'normal' conditions, and in the presence of exogenous, random (positive/negative) shocks. In addition, we studied the impact of BAS/BIS market composition on market performance.

At the individual level and under normal trading conditions, our results indicate that high BAS individuals are more active traders, prefer riskier portfolios, and generate higher overall profits. High BIS subjects generate lower scalping and overall trading profits. In terms of responses to shocks, high BAS traders respond to both negative and positive shocks with the same strategy: buying even more shares. This strategy appears sensible after high shocks, given that upward price adaptation is slow and prices remain below the new fundamental value mostly until trading closes. Following negative shocks, however, slow downward adaptation and market price levels well above the new fundamental value for most of the remaining trading time imply

\footnotetext{
${ }^{19}$ Note that the model for underreaction in Table 5 is over-specified (prob $>\mathrm{F}=0.396$ ), because the control variables are jointly statistically insignifcant. When including only BAS and BIS, the resulting model is jointly significant at the $10 \%$ level (prob $>\mathrm{F}=0.072$ ).
} 
that, on average, this strategy is likely to result in lower trading profits. We interpret the observed pattern-increased preference for stocks independent of the direction of the shock-as follows.

A positive shock raises the expected value of the risky asset and, at the same time, reduces the associated risk. This implies that shares become relatively more attractive compared to the pre-shock setting. Prior research shows that especially high BAS individuals respond to approach-motivating stimuli (e.g., a positive shock) with more pronounced attentional narrowing (Gable and Harmon-Jones, 2010). High BAS sensitivity has been associated with increased (decreased) likelihood judgments for positive (negative) events (Rose, 2009). Such narrowing of attention implies a heightened focus on the possibility of a positive outcome from possessing shares. In contrast, a negative shock decreases the expected value of the asset, and of an investor's portfolio, and the more so the higher the proportion of shares held before the shock. Faced with a (substantially) reduced value of their portfolio following a negative shock, high BAS traders may try to 'make the best of a bad job'. They will focus their attention on the potentially positive return to the risky asset, which — should it materialize — would allow them to compensate as much as possible for the drop in value of their portfolios. Further, high BAS traders responded to positive shocks by increasing the frequency of scalping trades (although not their scalping profits). In line with prior research that has pointed to high BAS individuals' more pronounced (over-)confidence (Kim and Lee, 2011), we speculate that a possible reason for this behavior is that high BAS investors might be more (over-)confident regarding their trading skills and/or understanding of the implications of the shock, compared to low BAS individuals.

Positive shocks 'unfreeze' high BIS investors, inducing them to trade more frequently and to generate higher trading profits. However, negative shocks do not alter high BIS investors' trading behavior significantly. Indeed, research has shown that persons who are highly sensitive to punishment signals are more likely to develop negative expectations when faced with adverse stimuli (Avila et al., 1999; Zinbarg and Mohlman, 1998). As the BIS is responsive to signals of punishment, high BIS individuals' attentional focus is likely to be on the downside potential of 
risky assets-i.e., on the possibility of a realized value below the fundamental value. Negative shocks may simply be interpreted as a confirmation, implying that the effects of this skeptical view on trading behavior were already fully reflected in high BIS traders' pre-shock trading, while high shocks are positive surprises, hence significantly altering behavior (and performance).

At the market level, under normal trading conditions, markets with a high BIS median (compared to low BIS median markets) are characterized by lower volatility. As they trade less frequently and arguably more cautiously, high BIS traders have a tendency to stick more closely to trading around the fundamental value, especially when it comes to purchasing shares. Further, heterogeneity within a market in terms of BAS sensitivity affects market outcomes. Higher BAS kurtosis (greater mass of individuals' BAS scores at the center) is associated with better efficiency and liquidity, compared to lower BAS kurtosis markets. This makes sense as the presence of more extreme BAS traders (fatter tails with very high and low BAS sensitivity) is likely to drive prices further apart, leading to a higher bid-ask spread. Also, high BAS traders are likely to be more willing to 'gamble' on positive outcomes of the lottery draw and, consequently, to pay higher prices, leading to a higher RMSE. For shock-trading, positive shocks in high BIS median markets (compared to low BIS median markets) lead to improved efficiency, lower bid-ask spread, and lower volatility. In line with the individual-level results, a positive shock 'unfreezes' high BIS traders. They participate more frequently in the market process. This benefits their individual profits, but market efficiency, liquidity, and volatility also benefit from the increased presence of 'cautious' BIS traders, who are less likely to buy for prices that exceed fundamental values, and more likely to contribute to trading activity around the (new) fundamental value. For negative shocks, we do not observe any significant effects of market composition.

Overall, this study makes several contributions to the literature. First, it provides evidence that two dimensions of motivational systems that are central to psychological research but have not yet been studied in a financial setting impact investors' strategies and performance in (experimental) asset markets. Differences in BAS sensitivity had more pronounced effects on, for 
example, portfolio structure than variations in other personality traits that have previously been studied, and were included as control variables, such as, for example, locus-of-control (McInish, 1982). Second, this study analyzes the effect of investors' personal characteristics in a novel trading environment: one that is subject to fundamental shocks. Third, it links individual-level variables to market outcomes, and documents a subtle pattern of effects with a market's level of BIS sensitivity and its heterogeneity with respect to BAS sensitivity emerging as the strongest influences. Given the limited number of sessions, these market-level results should, however, be interpreted as exploratory, indicating a need for future research to corroborate and extend these first results. Another major task for future research is to probe whether our results generalize to other subject pools, including professional investors (e.g., Ackert and Church, 2001; Biais and Weber, 2009; Chen et al., 2007; Haigh and List, 2005; Lo et al., 2005). Further, moderating effects of market microstructure (Ackert et al., 2006; Theissen, 2000; O’Hara 1995) such as, for example, variations in short-selling rules (Ackert et al., 2006) should be investigated. Short sellingespecially in a shock environment—-may appeal in particular to high BIS traders, implying that its inclusion might allow for obtaining a more comprehensive picture of the effects of differences in BAS/BIS sensitivity on trading strategies and performance. 


\section{References}

Ackert, L.F., \& Deaves, R. (2010). Behavioral Finance: Psychology, Decision-Making, and Markets. Mason, $\mathrm{OH}$ : South-Western Cengage Learning.

Ackert, L.F., \& Church, B.K. (2001). The effects of subject pool and design experience on rationality in experimental asset markets. Journal of Psychology and Financial Markets, 2(1): 6-28.

Ackert, L.F., Charupat, N., Church, B.K., \& Deaves, R. (2006). Margin, short selling, and lotteries in experimental asset markets. Southern Economic Journal, 73(2): 419-436.

Avila, C., Parcet, M.A., Ortet, G., \& Ibánez-Ribes, M.I. (1999). Anxiety and counterconditioning: The role of the behavioral inhibition system in the ability to associate aversive stimuli with future rewards. Personality and Individual Differences, 27, 1167-1179.

Bagozzi, R., \& Yi, Y. (1988). On the evaluation of structural equation models. Journal of the Academy of Marketing Science, 16, 74-94.

Barber, B.M., \& Odean, T. (2001). Boys will be boys: Gender, overconfidence and common stock investment. Quarterly Journal of Economics, 116(1), 261-292.

Barberis, N., Shleifer, A., \& Vishny, R.. (1998). A model of investor sentiment. Journal of Financial Economics, 49, 307-343.

Barrick M.R., Stewart G.L., Neubert M.J., \& Mount M.K. (1998). Relating member ability and personality to work team processes and team effectiveness. Journal of Applied Psychology, 83: 377-391.

Belsley D.A., Kuh, E., \& Welsch, R.E. (1980). Regression Diagnostics. New York, NY: John Wiley.

Biais, B., Hilton, D., Mazurier, K., \& Pouget, S. (2005). Judgmental overconfidence, selfmonitoring, and trading performance in an experimental financial market. Review of Economic Studies, 72, 287-312.

Biais, B., \& Weber, M. (2009). Hindsight bias, risk perception and investment performance. Management Science, 55, 1018-1029.

Bloomfield, R.J., Tayler, W.B., \& Zhou, F. (2009). Momentum, reversal, and uninformed traders in laboratory markets. Journal of Finance, 64, 2535-2558.

Brenner, S.L., Beauchaine, T.P., \& Sylvers, P.D. (2005). A comparison of psychophysiological and self-report measures of BAS and BIS activation. Psychophysiology, 42, 108-115.

Carver, C.S., \& White, T.L. (1994). Behavioral inhibition, behavioral activation, and affective responses to impending reward and punishment: the BIS/BAS scales. Journal of Personality and Social Psychology, 67, 319-333.

Chen, G., Kim, K.A., Nofsinger, J.R., \& Rui, O.M. (2007). Trading performance, disposition effect, overconfidence, representativeness bias and experience of emerging market investors. Journal of Behavioral Decision Making, 20, 425-451.

Chui, P.M.W. (2001). An experimental study of the disposition effect: Evidence from Macau. Journal of Psychology and Financial Markets, 2, 216-222.

Cloninger, C.R. (1987). A systematic method for clinical description and classification of personality variants. Archives of General Psychiatry, 44, 573-588.

Costa, P.T., \& McCrae, R.R.. (1992a). NEO PI-R Professional Manual. Odessa, FL: Psychological Assessment Resources.

Costa, P.T., \& McCrae, R.R.. (1992b). Four ways five factors are basic. Personality Individual Differences, 135, 653-665.

Cronbach, L.J. (1951). Coefficient alpha and the internal structure of a test. Psychometrika, 16, 297-334.

Curcuru, S., Heaton, J., Lucas, D., \& Moore, D. (2009). Heterogeneity and portfolio choice: Theory and evidence. In Y. Ait-Sahalia, L.P. Hansen (eds.). Handbook of Financial Econometrics. Amsterdam: Elsevier.

Da Costa, N., Mineto, C., \& Da Silva, S. (2008). Disposition effect and gender. Applied Economics Letters, 15, 429-437.

Daniel, K., Hirshleifer, D., Subrahmanyam, A. (1998). Investor psychology and security market 
under- and overreaction. Journal of Finance, 53, 1839-1885.

Deaves, R., Lüders, E., \& Luo, G.Y. (2009). An experimental test of the impact of overconfidence and gender on trading activity. Review of Finance, 13, 555-575.

Depue, R.A., \& Iacono, W.G. (1989). Neurobehavioral aspects of affective disorders. Annual Review of Psychology, 40, 457-492.

Dhar, R., \& Zhu, N. (2006). Up close and personal: Investor sophistication and the disposition effect. Management Science, 52, 726-740.

Einiö, M., Kaustia, M., \& Puttonen, V. (2008). Price setting and the reluctance to realize losses in apartment markets. Journal of Economic Psychology, 29: 19-34.

Fama, E.F. (1970). Efficient capital markets: A review of theory and empirical work. Joumal of Finance, 25(2), 383-417.

Fellner, G., \& Maciejovsky, B. (2007). Risk attitude and market behavior: Evidence from experimental asset markets. Journal of Economic Psychology, 28: 338-350.

Fenton-O'Creevy, M., Nicholson, N., Soane, E., \& Willman, P. (2005). Traders: Risks, Decisions, and Management in Financial Markets. Oxford, UK: Oxford University Press.

Fischbacher, U. (2007). Z-Tree: Zurich toolbox for ready-made economic experiments. Experimental Economics, 10, 171-178.

Forbes, J., \& Kara, S,M, (2010). Confidence mediates how investment knowledge influences investing self-efficacy. Journal of Economic Psychology, 31: 435-443.

Fowles, D.C. (1980). The three-arousal model: Implications of ray's two-factor learning theory for heart rate, electrodermal activity, and psychopathy. Psychophysiology, 17, 87-104.

Fowles, D.C. (1988). Psychophysiology and psychopathology: A motivational approach. Psychophysiology, 25, 373-391.

Fowles, D.C. (1993). Biological variables in psychopathology: A psychobiological perspective. In P.B. Sutker, H.E. Adams (eds.). Comprehensive Handbook of Psychopathology, $2^{\text {nd }}$ ed. New York, NY: Plenum, pp. 57-82.

Franken, I.H.A., \& Muris, P. (2005). Individual differences in decision making. Personality Individual Differences, 39, 991-998.

Gable, P., Harmon-Jones, E. (2010). The motivational dimensional model of affect: Implications for breadth of attention, memory, and cognitive categorization. Cognition \& Emotion, 24, 322337.

Gächter S., Johnson, E.J., \& Herrmann, A. (2007). Individual-level loss aversion in riskless and risky choices. CeDEx Discussion Paper No. 2007-02.

Genesove, D., \& Mayer, C. (2001). Loss aversion and seller behavior: Evidence from the housing market. Quarterly Journal of Economics, 116, 1233-1260.

Gneezy, U., Kapteyn, A., Potters, J. (2003). Evaluation periods and asset prices in a market experiment. Journal of Finance, 58, 821-837.

Gray, J.A. (1982). The Neuropsychology of Anxiety: An Enquiry into the Functions of the Septo-Hippocampal System. New York, NY: Oxford University Press.

Gray, J.A. (1987). The Psychology of Fear and Stress. Cambridge, UK: Cambridge University Press.

Gray, J. A. (1994). Personality dimensions and emotion systems. In P. Ekman, R. J. Davidson (eds.). The Nature of Emotion. New York, NY: Oxford University Press, pp. 329-331.

Grinblatt, M., \& Keloharju, M. (2009). Sensation seeking, overconfidence, and trading activity. Journal of Finance, 64, 549-578.

Haigh, M.S., \& List, J.A. (2005). Do professional traders exhibit myopic loss aversion? An experimental analysis. Journal of Finance, 60, 523-534.

Hair, J.F. Jr., Black, W.C. , Babin, B.J., Anderson, R.E., \& Tatham, R.L. (2006). Multivariate Data Anlysis ( ${ }^{\text {th }}$ ed.). Upper Saddle River, NJ: Pearson Prentice-Hall.

Holt C.A., \& Laury, S.K. (2002). Risk aversion and incentive effects. American Economic Review, 92, $1644-1655$. 
Huber, P. (1967). The behavior of maximum likelihood estimates under non-standard conditions. Proceedings of the Fifth Berkeley Symposium on Mathematical Statistics and Probability, Vol. 1. Berkeley, CA: University of California Press, 221-233.

Kahneman, D., \& Tversky, A. (1979). Prospect Theory: An analysis of decision under risk. Econometrica, 47(2), 263-292.

Kim, D.-Y, Lee, J.-H. 2011. Effects of the BAS and BIS on decision-making in a gambling task. Personality and Individual Differences, 50(7), 1131-1135.

Kirchler, M. (2009). Underreaction to fundamental information and asymmetry in mispricing between bullish and bearish markets. An experimental study. Journal of Economic Dynamics and Control, 33, 491-506.

Knutson, B., \& Bossaerts, P. (2007). Neural antecedents of financial decisions. Journal of Neuroscience, 27, 8174-8177.

Lakey, C.E., Rose, P., Campbell, W.K., \& Goodies, A.S. (2008). Probing the link between narcissism and gambling: The mediating role of judgment and decision making biases. Journal of Behavioral Decision Making, 21, 113-137.

Liu, H.-H. (2011). Impact of regulatory focus on ambiguity aversion. Journal of Behavioral Decision Making, 24, 412-430.

Lo, A.W., Repin, D.V., \& Steenbarger, B.N. (2005). Fear and greed in financial markets: A clinical study of day-traders. American Economic Review, 95, 352-359.

Loibl, C., \& Hira, T.K. (2009). Investor information search. Journal of Economic Psychology, 30: 2441.

McInish, T.H. (1980). A game-simulation of stock market behavior: An extension. Simulations Games, 11, 477-484.

McInish, T.H. (1982). Individual investors and risk-taking. Journal of Economic Psychology, 2, 125 136.

McInish, T.H., \& Srivastava, R.K. (1984). The nature of individual investors' heterogeneous expectations. Journal of Economic Psychology, 5: 251-263.

Neuman G.A., Wagner S.H., \& Christiansen N.D. (1999). The relationship between work team personality composition and the job performance of teams. Group \& Organization Management, 24: $28-45$.

Odean, T. (1998). Are investors reluctant to realize their losses? Journal of Finance, 53, 1775-1798.

Odean, T. (1999). Do investors trade too much? American Economic Review, 89, 1279-1298.

O'Hara, M. 1995. Market Microstructure Theory. Blackwell Business, Cambridge, MA.

Oliven, K., \& Rietz, T.A. (2004). Suckers are born but markets are made: Individual rationality, arbitrage, and market efficiency on an electronic futures market. Management Science, 50, 336351.

Powell, M., \& Ansic, D. (1997). Gender differences in risk behaviour in financial decisionmaking: An experimental analysis. Journal of Economic Psychology, 18: 605-628.

Prévost, C., McCabe, J.A., Jessup, R.K., Bossaerts, P., \& O’Doherty, J.P. (2011). Differentiable contributions of human amygdalar subregions in the computations underlying reward and avoidance learning. European Journal of Neuroscience, 34, 134-145.

Quay, H.C. (1988). The Behavioral Reward and Inbibition System in Childhood Behavior Disorder. Elmsford, NY: Pergamon Press.

Rabin, M. (2000). Risk aversion and expected-utility theory: A calibration theorem. Econometrica, $68,1281-1293$.

Rose, J.P. (2009). Approach-avoidance and optimism. Unpublished Ph.D. dissertation, Iowa, IA: University of Iowa.

Rotter, J. B. (1966). Generalized expectancies for internal versus external control of reinforcement. Psychological Monographs, Complete number 609.

Sachse, K., Jungermann, H., \& Belting, J.M. (2012). Investment risk - The perspective of individual investors. Journal of Economic Psychology, 33: 437-447. 
Shefrin, H., \& Statman, M. (1985). The disposition to sell winners too early and ride losers too long; theory and evidence. Journal of Finance, 40, 777-790.

Smith, V.L., Suchanek, G.L., \& Williams, A.W. (1988). Bubbles, crashes and endogenous expectations in experimental asset spot markets. Econometrica, 56, 1119-1151.

Snyder, M., \& Gangestad, S. (1986). On the nature of self-monitoring. Journal of Personality and Social Psychology, 51, 125-139.

Stracca, L. (2004). Behavioral finance and asset prices: Where do we stand? Journal of Economic Psychology, 25: 373-405.

Studenmund A.H. (1992). Using Econometrics: A Practical Guide. New York, NY: Harper Collins.

Thayer, R. E. (1986). Activation (arousal): The shift from a single to a multidimensional perspective. In J. Strelau, F. Farley, A. Gale (eds.). The Biological Basis of Personality and Behavior Vol. 1. London, UK: Hemisphere, pp. 115-127.

Theissen, E. (2000). Market structure, informational efficiency, and liquidity: An experimental comparison of auction and dealer markets. Journal of Financial Markets, 3, 333-363.

Tom, S.M., Fox, C.R., Trepel, C., \& Poldrack, R.A. (2007). The neural basis of loss aversion in decision making under risk. Science, 315, 515-518.

Tversky, A., \& Kahneman, D. (1974). Judgment under uncertainty: Heuristics and biases. Science, 185, 1124-1131.

Van Honk, J., Hermans, E.J., Putman, P., Montagne, B., \& Schutter, D.J. (2002). Defective somatic markers in sub-clinical psychopathy. Neuroreport, 13, 1025-1027.

Watson, D., Wiese, D., Vaidya, J., \& Tellegen, A. (1999). The two general activation systems of affect: structural findings, evolutionary considerations, and psychobiological evidence. Joumal of Personality and Social Psychology, 76, 820-838.

Weber, M., \& Welfens, F. (2007). How do markets react to fundamental shocks? An experimental analysis on underreaction and momentum. Available at: http:/ / ssrn.com/abstract $=1022924$.

White, H. (1980). A heteroskedasticity-consistent covariance matrix estimator and a direct test for heteroskedasticity. Econometrica, 48, 817-838.

Zinbarg, R.E., \& Mohlman, J. (1998). Individual differences in the acquisition of affectively valenced associations. Journal of Personality and Social Psychology, 74, 1024-1040.

Zuckerman, M. (1994). Behavioral Expressions and Biosocial Bases of Sensation Seeking. Cambridge, UK: Cambridge University Press.

Zuckerman, M. (1979). Sensation Seeking: Beyond the Optimal Level of Arousal. New York, NY: John Wiley. 


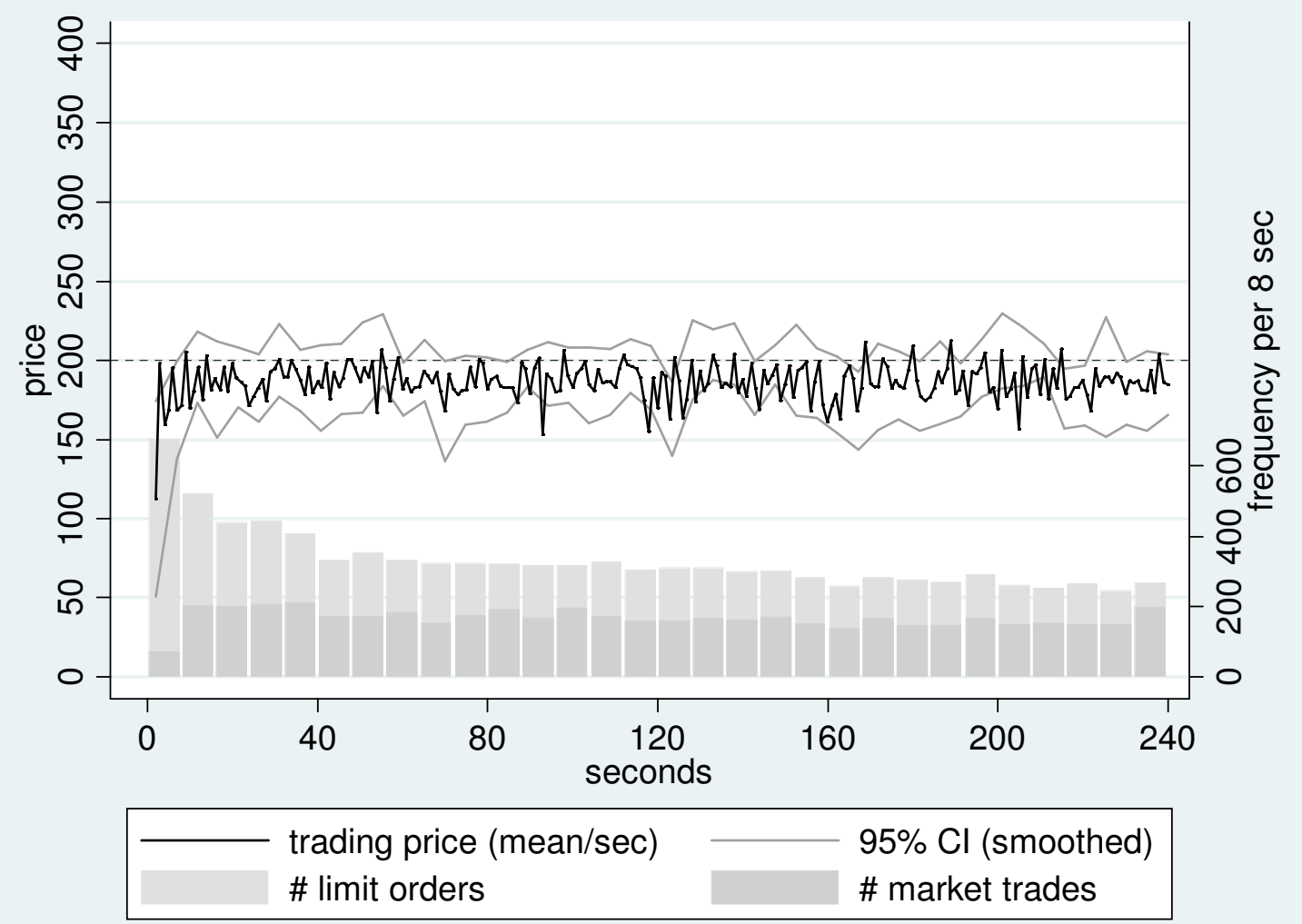

Figure 1: Prices, order and trading volumes during treatment T1 (NORM) 


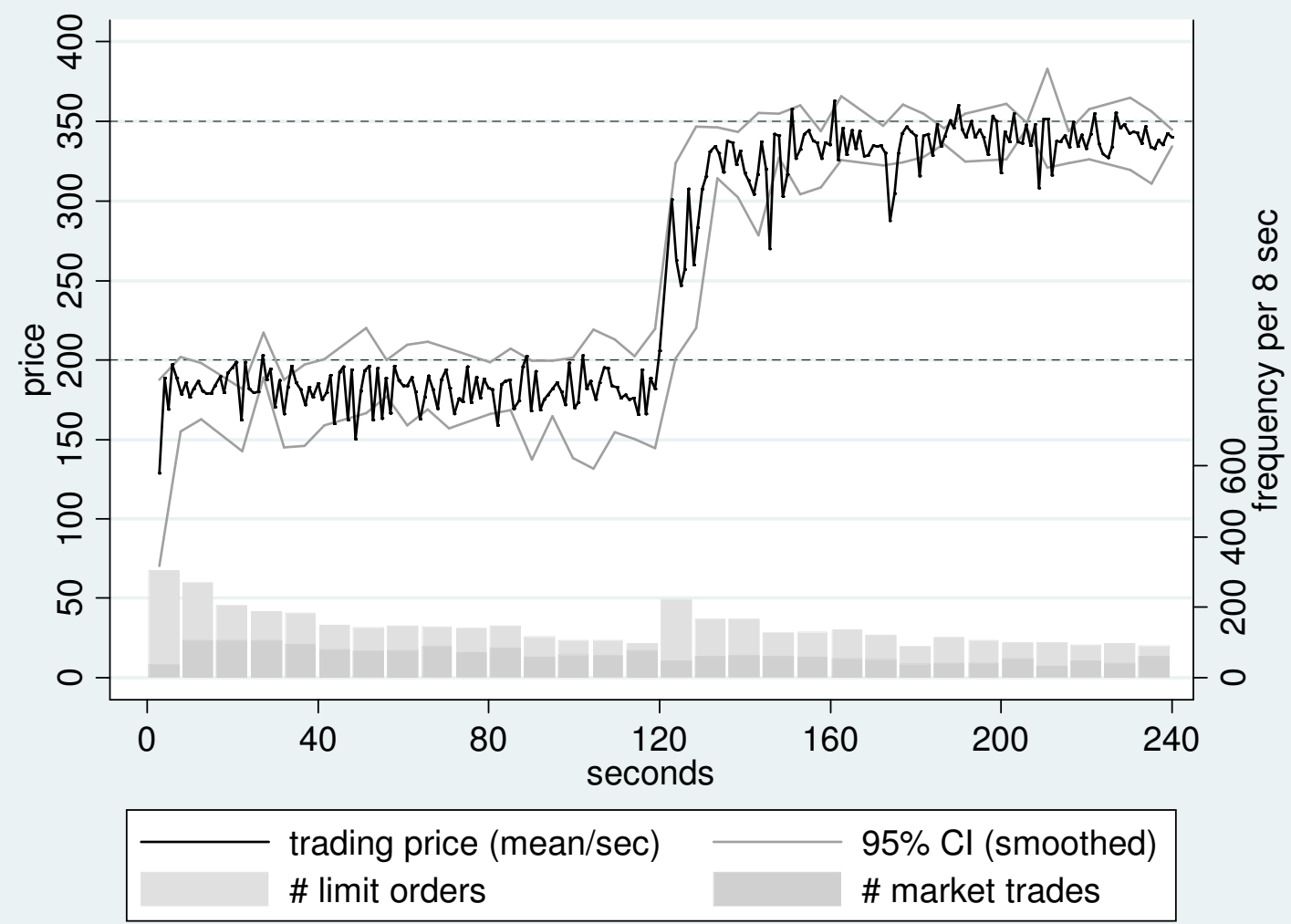

Figure 2: Prices, order and trading volumes during treatment T2 (SHOCK) with positive shock (sub-treatment: T2-POST HI) 


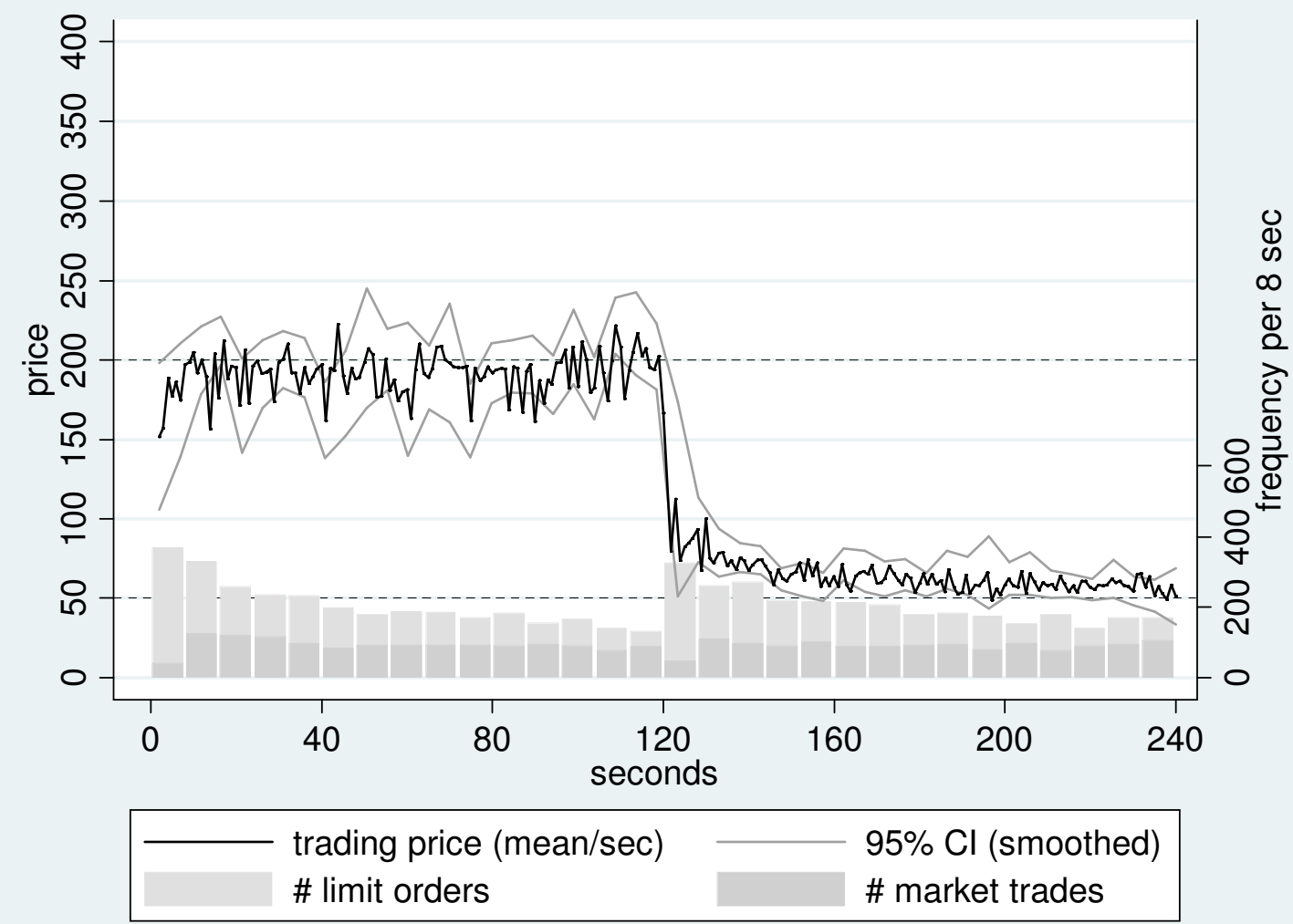

Figure 3: Prices, order and trading volumes during treatment T2 (SHOCK) with negative shock (sub-treatment: T2-POST LO) 


\begin{tabular}{|c|c|c|c|c|c|c|c|c|c|c|c|c|c|c|c|c|c|c|}
\hline & & mean & $\mathrm{sd}$ & $\min$ & $\max$ & 1 & 2 & 3 & 4 & 5 & 6 & 7 & 8 & 9 & 10 & 11 & 12 & 13 \\
\hline 1 & BAS & 3.416 & 0.379 & 2.4 & 4 & 1 & & & & & & & & & & & & \\
\hline 2 & BIS & 2.907 & 0.501 & 1.571 & 3.857 & $0.303^{*}$ & 1 & & & & & & & & & & & \\
\hline 3 & Locus-of-control & 11.18 & 4.33 & 2 & 23 & -0.047 & $-0.347 *$ & 1 & & & & & & & & & & \\
\hline 4 & Thrill \& adventure seeking & 6.632 & 2.537 & 0 & 10 & 0.020 & $-0.226^{*}$ & 0.139 & 1 & & & & & & & & & \\
\hline 6 & Self-monitoring & 9.807 & 3.282 & 2 & 17 & 0.133 & $-0.183^{*}$ & 0.109 & $0.186^{*}$ & 0.03 & 1 & & & & & & & \\
\hline 7 & Loss aversion & 4.415 & 1.422 & 1 & 7 & 0.058 & 0.111 & -0.038 & $-0.164^{*}$ & -0.091 & -0.049 & 1 & & & & & & \\
\hline 8 & Risk attitude & 4.193 & 1.861 & 1 & 10 & 0.056 & -0.051 & 0.093 & 0.135 & 0.023 & 0.072 & $-0.256^{*}$ & 1 & & & & & \\
\hline 9 & Age & 21.38 & 2.389 & 17 & 31 & 0.051 & -0.004 & 0.059 & -0.098 & 0.059 & -0.031 & 0.117 & -0.047 & 1 & & & & \\
\hline & Female & 0.655 & 0.477 & 0 & 1 & $0.214^{*}$ & $0.337^{*}$ & $-0.285^{*}$ & $-0.229 *$ & -0.149 & -0.107 & $0.212^{*}$ & -0.032 & 0.064 & 1 & & & \\
\hline & Friends & 0.234 & 0.425 & 0 & 1 & -0.079 & -0.117 & 0.052 & 0.084 & -0.103 & 0.083 & -0.048 & 0.011 & -0.036 & 0.081 & 1 & & \\
\hline & Business_Economics & 0.374 & 0.485 & 0 & 1 & $-0.164 *$ & $-0.195^{*}$ & $0.177 *$ & 0.133 & 0.142 & -0.009 & -0.097 & 0.04 & $-0.230 *$ & $-0.252^{*}$ & 0.087 & 1 & \\
\hline & Master_PhD & 0.503 & 0.501 & 0 & 1 & -0.119 & -0.004 & 0.025 & 0.067 & 0.016 & 0.036 & -0.047 & 0.001 & $0.360^{*}$ & -0.057 & -0.059 & -0.077 & 1 \\
\hline & Financial experience & 2.754 & 1.575 & 1 & 9 & 0.083 & -0.115 & 0.084 & 0.023 & -0.043 & 0.077 & -0.031 & -0.045 & 0.066 & $-0.208^{*}$ & $-0.151 *$ & $0.244^{*}$ & 0.105 \\
\hline
\end{tabular}

Table 1: Descriptive statistics and bivariate correlations for individual level variables 


\begin{tabular}{|c|c|c|c|c|c|}
\hline & \multicolumn{5}{|c|}{ Normal trading (T1-NORM) } \\
\hline & No. of shares & $\begin{array}{l}\text { Trading } \\
\text { profits }\end{array}$ & $\begin{array}{l}\text { Trading } \\
\text { frequency }\end{array}$ & $\begin{array}{l}\text { Scalping } \\
\text { frequency }\end{array}$ & $\begin{array}{c}\text { Scalping } \\
\text { profits }\end{array}$ \\
\hline \multirow{2}{*}{$B A S$} & $0.152^{* * *}$ & $0.095^{* * *}$ & $0.120 * * *$ & $0.075^{* *}$ & 0.03 \\
\hline & {$[4.852]$} & [2.371] & {$[3.561]$} & [2.069] & {$[0.846]$} \\
\hline \multirow[t]{2}{*}{ BIS } & -0.047 & $-0.093 * * *$ & -0.04 & -0.034 & $-0.092 * * *$ \\
\hline & {$[-1.168]$} & {$[-2.917]$} & {$[-1.071]$} & {$[-0.928]$} & {$[-3.257]$} \\
\hline \multirow[t]{2}{*}{ Locus-of-control } & -0.058 & 0.042 & $0.064 *$ & 0.054 & -0.002 \\
\hline & {$[-1.644]$} & [1.319] & {$[1.723]$} & [1.482] & {$[-0.058]$} \\
\hline \multirow[t]{2}{*}{$T A S$} & -0.011 & -0.001 & $0.072 * *$ & $0.113^{* * *}$ & -0.013 \\
\hline & {$[-0.296]$} & {$[-0.034]$} & {$[2.262]$} & [3.486] & {$[-0.411]$} \\
\hline \multirow[t]{2}{*}{ Self-monitoring } & $0.058^{*}$ & $0.072^{* *}$ & -0.011 & 0.009 & -0.001 \\
\hline & [1.942] & {$[2.380]$} & {$[-0.332]$} & {$[0.261]$} & {$[-0.019]$} \\
\hline \multirow[t]{2}{*}{ Loss aversion } & $-0.120^{* * *}$ & -0.029 & 0.023 & $0.057 *$ & 0.023 \\
\hline & {$[-3.371]$} & {$[-0.774]$} & {$[0.839]$} & [1.923] & {$[0.585]$} \\
\hline \multirow[t]{2}{*}{ Risk attitude } & 0.004 & -0.048 & $0.132^{* * *}$ & $0.117 * * *$ & $-0.052^{*}$ \\
\hline & {$[0.115]$} & {$[-1.387]$} & {$[4.603]$} & {$[3.788]$} & {$[-1.773]$} \\
\hline \multirow[t]{2}{*}{ Age } & -0.018 & $-0.188^{* * *}$ & $0.057^{*}$ & $0.063^{*}$ & $-0.181 * * *$ \\
\hline & {$[-0.470]$} & {$[-4.583]$} & [1.718] & [1.693] & [-4.209] \\
\hline \multirow[t]{2}{*}{ Female } & 0.092 & $-0.237 * * *$ & $-0.168^{* *}$ & -0.072 & $-0.208 * * *$ \\
\hline & [1.460] & {$[-3.131]$} & {$[-2.161]$} & {$[-0.932]$} & {$[-2.633]$} \\
\hline \multirow[t]{2}{*}{ Friends } & $0.167 * * *$ & -0.015 & 0.024 & -0.024 & $-0.135^{*}$ \\
\hline & {$[2.806]$} & {$[-0.176]$} & {$[0.425]$} & {$[-0.394]$} & {$[-1.686]$} \\
\hline \multirow[t]{2}{*}{ Business_Economics } & 0.105 & $0.146^{* *}$ & $-0.158^{* *}$ & $-0.152^{* *}$ & 0.094 \\
\hline & [1.353] & [1.683] & {$[-2.513]$} & {$[-2.467]$} & [1.288] \\
\hline \multirow[t]{2}{*}{ Master_PhD } & -0.034 & $0.194^{* *}$ & -0.027 & -0.06 & 0.069 \\
\hline & {$[-0.453]$} & [2.487] & {$[-0.346]$} & {$[-0.812]$} & {$[1.037]$} \\
\hline \multirow[t]{2}{*}{ Financial experience } & -0.017 & -0.019 & $-0.088^{* * *}$ & $-0.066^{* *}$ & -0.022 \\
\hline & {$[-0.561]$} & {$[-0.652]$} & [-2.664] & {$[-2.050]$} & {$[-0.686]$} \\
\hline \multirow[t]{2}{*}{ Market size } & $-0.010^{* *}$ & $0.019 * * *$ & 0.004 & 0.001 & $0.021 * *$ \\
\hline & {$[-2.287]$} & {$[3.058]$} & {$[0.281]$} & {$[0.105]$} & [2.245] \\
\hline \multirow[t]{2}{*}{ Intercept } & $0.118^{* *}$ & $-0.226 * * *$ & -0.046 & -0.015 & $-0.25^{* *}$ \\
\hline & [2.225] & {$[-3.083]$} & {$[-0.262]$} & {$[-0.100]$} & {$[-2.214]$} \\
\hline $\begin{array}{l}\text { No. of } \\
\text { observations }\end{array}$ & 1,026 & 1,026 & 1,026 & 1,026 & 1,026 \\
\hline $\mathrm{R} 2$ & 0.05 & 0.091 & 0.065 & 0.054 & 0.059 \\
\hline prob $>$ F & 0.000 & 0.000 & 0.000 & 0.000 & 0.000 \\
\hline
\end{tabular}

Table 2: Regression results for individual-level variables during normal trading (T1; NORM) 


\begin{tabular}{|l|r|r|r|}
\hline Variable & \multicolumn{3}{|c|}{ NORM (T1) } \\
\hline (market level) & $\begin{array}{c}\text { RMSE } \\
\text { (Efficiency) }\end{array}$ & $\begin{array}{c}\text { Bid-ask spread } \\
\text { (Liquidity) }\end{array}$ & $\begin{array}{c}\text { s.d. of traded prices } \\
\text { (Volatility) }\end{array}$ \\
\hline BAS median & $-27.88[-0.746]$ & $28.007[0.604]$ & $10.402[0.560]$ \\
\hline BIS median & $-0.865[-0.028]$ & $-53.485[-1.297]$ & $-38.196^{* *}[-2.172]$ \\
\hline BAS kurtosis & $-14.373^{\dagger}[-1.647]$ & $-17.195^{* * *}[-3.084]$ & $-3.733[-1.349]$ \\
\hline BIS kurtosis & $-22.881[-1.482]$ & $6.024[0.388]$ & $-2.371[-0.375]$ \\
\hline Intercept & $214.837^{* *}[2.452]$ & $142.283[0.825]$ & $104.256[1.473]$ \\
\hline $\mathrm{N}$ & 90 & 90 & 90 \\
\hline R2 & 0.413 & 0.204 & 0.264 \\
\hline prob > F & 0.089 & 0.025 & 0.075 \\
\hline
\end{tabular}

Table 3: Regression results for effects of market composition (BIS, BAS) on market-level performance measures during normal trading (T1; NORM) $\left({ }^{\dagger} p<0.13,{ }^{*} p<0.1,{ }^{* *} p<0.05\right.$, *** $p<0.01$; $[$-values in parentheses; heteroskedasticity-consistent (robust) standard errors (clustered) at session level]). 


\begin{tabular}{|c|c|c|c|c|c|c|}
\hline & \multicolumn{5}{|c|}{$\begin{array}{l}\text { Post-high shock trading - Pre-shock trading } \\
\text { (T2-POST HI - PRE-SHOCK ) }\end{array}$} & \multirow{2}{*}{$\begin{array}{c}\begin{array}{c}\text { Post- } \\
\text { positive } \\
\text { shock } \\
\text { trading }\end{array} \\
\text { Under- } \\
\text { reaction }\end{array}$} \\
\hline & $\begin{array}{l}\text { No. of } \\
\text { shares }\end{array}$ & $\begin{array}{l}\text { Trading } \\
\text { profits }\end{array}$ & $\begin{array}{l}\text { Trading } \\
\text { frequency }\end{array}$ & $\begin{array}{l}\text { Scalping } \\
\text { frequency }\end{array}$ & $\begin{array}{c}\text { Scalping } \\
\text { profits }\end{array}$ & \\
\hline \multirow[t]{2}{*}{$B A S$} & $0.099 *$ & -0.022 & -0.039 & $0.118^{* * *}$ & -0.029 & 0.017 \\
\hline & {$[2.064]$} & {$[-0.303]$} & {$[-0.702]$} & [2.731] & {$[-0.414]$} & [0.233] \\
\hline \multirow[t]{2}{*}{$B I S$} & -0.034 & $0.170^{* *}$ & $0.117 *$ & 0.005 & 0.027 & -0.043 \\
\hline & {$[-0.491]$} & {$[2.076]$} & {$[1.830]$} & [0.100] & [0.533] & {$[-0.639]$} \\
\hline \multirow[t]{2}{*}{ Locus-of-control } & 0.004 & -0.045 & 0.106 & -0.016 & 0.027 & -0.077 \\
\hline & {$[0.072]$} & {$[-0.814]$} & {$[1.554]$} & {$[-0.276]$} & {$[0.408]$} & [-1.099] \\
\hline \multirow[t]{2}{*}{$T A S$} & 0.061 & 0.001 & 0.081 & $-0.091 *$ & -0.019 & 0.039 \\
\hline & [1.093] & {$[0.027]$} & {$[1.587]$} & [-1.941] & {$[-0.354]$} & {$[0.547]$} \\
\hline \multirow[t]{2}{*}{ Self-monitoring } & 0.026 & 0.063 & -0.073 & $-0.119 * * *$ & -0.007 & -0.017 \\
\hline & {$[0.460]$} & {$[0.789]$} & {$[-1.602]$} & {$[-3.001]$} & {$[-0.142]$} & {$[-0.253]$} \\
\hline \multirow[t]{2}{*}{ Loss aversion } & -0.012 & 0.014 & -0.041 & -0.054 & -0.097 & 0.079 \\
\hline & {$[-0.175]$} & {$[0.205]$} & {$[-0.994]$} & {$[-1.075]$} & {$[-1.667]$} & [1.562] \\
\hline \multirow[t]{2}{*}{ Risk attitude } & $-0.120^{*}$ & -0.053 & -0.067 & $-0.100 * *$ & $-0.070 * *$ & $0.086^{*}$ \\
\hline & [-1.721] & {$[-1.535]$} & {$[-1.547]$} & {$[-2.293]$} & {$[-2.103]$} & [-1.726] \\
\hline \multirow[t]{2}{*}{ Age } & -0.069 & -0.022 & $-0.151 * *$ & $-0.170^{* *}$ & -0.066 & 0.098 \\
\hline & {$[-1.161]$} & {$[-1.014]$} & {$[-2.506]$} & {$[-2.591]$} & {$[-1.314]$} & [1.475] \\
\hline \multirow[t]{2}{*}{ Female } & 0.015 & $-0.158^{*}$ & 0.072 & -0.013 & -0.078 & 0.15 \\
\hline & [0.132] & [-1.729] & [0.555] & {$[-0.106]$} & {$[-0.590]$} & [0.885] \\
\hline \multirow[t]{2}{*}{ Friends } & -0.032 & $0.224 * *$ & 0.123 & 0.157 & -0.067 & 0.103 \\
\hline & {$[-0.257]$} & {$[2.293]$} & [1.081] & [1.607] & {$[-0.592]$} & {$[0.789]$} \\
\hline \multirow[t]{2}{*}{ Business_Economics } & $-0.194^{*}$ & -0.146 & 0.054 & $0.210 * *$ & 0.044 & $-0.204^{*}$ \\
\hline & {$[-1.981]$} & {$[-1.637]$} & [0.618] & {$[2.450]$} & {$[0.419]$} & [-1.694] \\
\hline \multirow[t]{2}{*}{ Master_PhD } & 0.094 & -0.051 & 0.031 & 0.053 & 0.045 & -0.097 \\
\hline & [0.853] & {$[-0.720]$} & [0.291] & {$[0.530]$} & {$[0.383]$} & {$[-0.754]$} \\
\hline \multirow[t]{2}{*}{ Financial experience } & -0.033 & $0.073^{*}$ & 0.053 & 0.03 & 0.056 & 0.048 \\
\hline & {$[-0.702]$} & [1.821] & [1.048] & {$[0.719]$} & [1.042] & {$[0.737]$} \\
\hline \multirow[t]{2}{*}{ Market size } & 0.004 & -0.006 & -0.009 & -0.006 & 0.006 & -0.017 \\
\hline & [0.439] & {$[-0.798]$} & {$[-0.427]$} & {$[-0.290]$} & {$[0.445]$} & {$[-0.409]$} \\
\hline \multirow[t]{2}{*}{ Intercept } & -0.048 & 0.062 & 0.114 & 0.082 & -0.07 & 0.188 \\
\hline & {$[-0.443]$} & {$[0.753]$} & [0.452] & [0.303] & {$[-0.414]$} & {$[0.387]$} \\
\hline No. of observations & 455 & 455 & 455 & 455 & 455 & 275 \\
\hline R2 & 0.038 & 0.045 & 0.061 & 0.089 & 0.027 & 0.05 \\
\hline prob $>$ F & 0.004 & 0.009 & 0.005 & 0.000 & 0.333 & 0.032 \\
\hline
\end{tabular}

Table 4: Regression results for individual-level variables during post shock trading behavior following a positive shock (T2-POST HI) 


\begin{tabular}{|c|c|c|c|c|c|c|}
\hline & \multicolumn{5}{|c|}{$\begin{array}{l}\text { Post-low shock trading - Pre-shock trading } \\
\text { (T2-POST LO - PRE-SHOCK ) }\end{array}$} & \multirow{2}{*}{$\begin{array}{c}\begin{array}{c}\text { Post- } \\
\text { positive } \\
\text { shock } \\
\text { trading }\end{array} \\
\text { Under- } \\
\text { reaction }\end{array}$} \\
\hline & $\begin{array}{l}\text { No. of } \\
\text { shares }\end{array}$ & $\begin{array}{l}\text { Trading } \\
\text { profits }\end{array}$ & $\begin{array}{l}\text { Trading } \\
\text { frequency }\end{array}$ & $\begin{array}{l}\text { Scalping } \\
\text { frequency }\end{array}$ & $\begin{array}{c}\text { Scalping } \\
\text { profits }\end{array}$ & \\
\hline \multirow[t]{2}{*}{$B A S$} & $0.170^{* * *}$ & -0.124 & $0.101 *$ & 0.023 & -0.081 & $0.134 * *$ \\
\hline & [3.534] & {$[-1.547]$} & {$[1.779]$} & [0.423] & {$[-1.441]$} & [2.283] \\
\hline \multirow[t]{2}{*}{$B I S$} & -0.012 & 0.073 & 0.068 & 0.073 & -0.014 & 0.034 \\
\hline & {$[-0.216]$} & {$[1.380]$} & {$[1.126]$} & [1.473] & {$[-0.283]$} & [0.487] \\
\hline \multirow[t]{2}{*}{ Locus-of-control } & -0.006 & 0.031 & 0.05 & $0.136^{* * *}$ & -0.026 & -0.019 \\
\hline & {$[-0.117]$} & {$[0.470]$} & {$[0.946]$} & {$[2.758]$} & {$[-0.430]$} & {$[-0.279]$} \\
\hline \multirow[t]{2}{*}{$T A S$} & -0.013 & 0.031 & 0.015 & -0.054 & 0.016 & -0.028 \\
\hline & {$[-0.239]$} & {$[0.407]$} & {$[0.346]$} & {$[-1.064]$} & {$[0.344]$} & {$[-0.446]$} \\
\hline \multirow[t]{2}{*}{ Self-monitoring } & 0.004 & $-0.121 * *$ & 0.001 & $-0.076^{*}$ & 0.004 & -0.03 \\
\hline & {$[0.086]$} & {$[-2.610]$} & [0.013] & {$[-1.987]$} & [0.085] & {$[-0.674]$} \\
\hline \multirow[t]{2}{*}{ Loss aversion } & 0.011 & 0.043 & 0.051 & 0.029 & -0.056 & 0.07 \\
\hline & {$[0.223]$} & {$[0.642]$} & {$[1.074]$} & {$[0.649]$} & {$[-1.430]$} & [1.355] \\
\hline \multirow[t]{2}{*}{ Risk attitude } & 0.035 & -0.097 & $0.109 * *$ & 0.035 & 0.05 & 0.074 \\
\hline & [0.684] & {$[-1.379]$} & {$[2.586]$} & {$[0.705]$} & [1.120] & [1.675] \\
\hline \multirow[t]{2}{*}{ Age } & $0.143^{* * *}$ & 0.048 & 0.025 & 0.011 & $0.145^{* * *}$ & -0.034 \\
\hline & [3.553] & {$[0.666]$} & {$[0.426]$} & [0.183] & [2.814] & {$[-0.586]$} \\
\hline \multirow[t]{2}{*}{ Female } & $-0.216^{*}$ & $0.353 * * *$ & $-0.349 * * *$ & -0.182 & 0.037 & -0.157 \\
\hline & {$[-1.951]$} & {$[2.835]$} & {$[-2.559]$} & {$[-1.553]$} & {$[0.317]$} & {$[-1.105]$} \\
\hline \multirow[t]{2}{*}{ Friends } & -0.083 & 0.112 & -0.045 & 0.019 & -0.023 & 0.189 \\
\hline & {$[-0.838]$} & {$[0.978]$} & {$[-0.476]$} & [0.159] & {$[-0.203]$} & [1.353] \\
\hline \multirow[t]{2}{*}{ Business_Economics } & $0.358^{* * *}$ & -0.284 & 0.089 & 0.097 & -0.047 & -0.1 \\
\hline & [3.652] & {$[-1.641]$} & {$[0.904]$} & {$[0.974]$} & {$[-0.533]$} & [-0.909] \\
\hline \multirow[t]{2}{*}{ Master_PhD } & 0.072 & 0.082 & $-0.242 * *$ & $-0.233 * *$ & -0.051 & 0.087 \\
\hline & [0.721] & {$[0.657]$} & {$[-2.360]$} & {$[-2.115]$} & {$[-0.608]$} & {$[0.716]$} \\
\hline \multirow[t]{2}{*}{ Financial experience } & -0.075 & 0.079 & -0.025 & 0.01 & $0.134 * * *$ & 0.042 \\
\hline & {$[-1.610]$} & [1.144] & {$[-0.516]$} & {$[0.208]$} & {$[3.001]$} & {$[0.713]$} \\
\hline \multirow[t]{2}{*}{ Market size } & $0.012^{* *}$ & $-0.025^{* * *}$ & 0.014 & 0.005 & -0.01 & -0.006 \\
\hline & [2.152] & {$[-2.784]$} & [0.686] & {$[0.277]$} & {$[-0.573]$} & {$[-0.208]$} \\
\hline \multirow[t]{2}{*}{ Intercept } & $-0.137 * *$ & $0.301 * * *$ & -0.167 & -0.065 & 0.117 & 0.068 \\
\hline & {$[-2.038]$} & [2.803] & {$[-0.694]$} & {$[-0.277]$} & [0.609] & [0.182] \\
\hline $\mathrm{N}$ & 571 & 571 & 571 & 571 & 571 & 368 \\
\hline R2 & 0.063 & 0.056 & 0.064 & 0.052 & 0.045 & 0.033 \\
\hline prob $>$ F & 0.000 & 0.002 & 0.007 & 0.000 & 0.042 & 0.396 \\
\hline
\end{tabular}

Table 5: Regression results for individual-level variables during post shock trading behavior following a negative shock (T2-POST LO) 


\begin{tabular}{|c|c|c|c|}
\hline \multirow{2}{*}{$\begin{array}{l}\text { Variable } \\
\text { (market level) }\end{array}$} & \multicolumn{3}{|c|}{ (a) Post-high shock trading - Pre-shock trading (T2) (T2-POST HI - PRE-SHOCK) } \\
\hline & $\begin{array}{c}\text { RMSE } \\
\text { (Efficiency) }\end{array}$ & $\begin{array}{l}\text { Bid-ask spread } \\
\text { (Liquidity) }\end{array}$ & $\begin{array}{c}\text { s.d. of traded prices } \\
\text { (Volatility) }\end{array}$ \\
\hline$B A S$ median & $-30.426[-1.132]$ & $23.923[0.692]$ & $-14.569[-0.760]$ \\
\hline BIS median & $-83.429 * * *[-3.930]]$ & $-55.674 *[-1.885]$ & $-36.751 *[-1.904]$ \\
\hline BAS kurtosis & $3.949[0.845]$ & $0.239[0.045]$ & $-0.788[-0.331]$ \\
\hline BIS kurtosis & $14.684[1.663]$ & $-9.162[-0.775]$ & $-7.555[-1.204]$ \\
\hline Intercept & $309.377 * *[2.885]]$ & $130.133[0.792]$ & $191.108 * *[2.245]$ \\
\hline & 40 & 40 & 40 \\
\hline & 0.264 & 0.156 & 0.161 \\
\hline prob $>$ F & 0.009 & 0.009 & 0.001 \\
\hline Variable & \multicolumn{3}{|c|}{ (b) Post-low shock trading - Pre-shock trading (T2) (T2-POST LO - PRE-SHOCK ) } \\
\hline (market level) & $\begin{array}{l}\text { RMSE } \\
\text { (Efficiency) }\end{array}$ & $\begin{array}{l}\text { Bid-ask spread } \\
\text { (Liquidity) }\end{array}$ & $\begin{array}{c}\text { s.d. of traded prices } \\
\text { (Volatility) }\end{array}$ \\
\hline$B A S$ median & $7.674[0.285]$ & $18.580[0.531]$ & $-4.808[-0.304]$ \\
\hline BIS median & $-7.398[-0.213]$ & $-18.052[-0.412]$ & $-15.087[-0.548]]$ \\
\hline BAS kurtosis & $3.672[0.441]$ & $6.832[0.825]$ & $-1.094[-0.214]$ \\
\hline BIS kurtosis & $21.695[1.550]$ & $15.144[1.225]$ & $13.009[1.412]$ \\
\hline Intercept & $-72.479[-0.782]$ & $-60.368[-0.663]$ & $37.433[0.611]$ \\
\hline $\mathrm{N}$ & 50 & 50 & 50 \\
\hline R2 & 0.171 & 0.125 & 0.107 \\
\hline prob $>$ F & 0.295 & 0.535 & 0.444 \\
\hline
\end{tabular}

Table 6: Regression results for effects of market composition (BIS, BAS) on market-level performance measures during (a) POST-SHOCK trading vs. PRE-SHOCK trading following a positive shock, and (b) POST-SHOCK trading vs. PRE-SHOCK trading following a negative shock ( $*<<0.1,{ }^{* *} p<0.05, * * * p<0.01$; [ $t$-values in parentheses; heteroskedasticity-consistent (robust) standard errors (clustered) at session level]). Results for all post-pre shock trading comparisons are qualitatively robust to the use of standardized measures. 
Appendix A1.

Table A1: Individual-level control variables (corresponding to tables II-VI) ${ }^{20}$

\begin{tabular}{|c|c|c|c|c|c|}
\hline Variable & Measurement scale & $\begin{array}{l}\text { Source/ } \\
\text { definition }\end{array}$ & $\begin{array}{l}\text { Cronbach's } \\
\alpha\end{array}$ & $\begin{array}{l}\text { Minimum possible } \\
\text { score }\end{array}$ & $\begin{array}{l}\text { Maximum possible } \\
\text { score }\end{array}$ \\
\hline Locus-of-control & 23 forced-choice items & Rotter (1966) & .756 & 0 (external) & 23 (internal) \\
\hline $\begin{array}{l}\text { Thrill and } \\
\text { Adventure Seeking } \\
(T A S)\end{array}$ & Ten forced binary choice items & $\begin{array}{l}\text { Sub-scale from } \\
\text { Zuckerman's updated } \\
\text { Sensation Seeking Scale V; } \\
\text { Zuckerman }(1979,1994)\end{array}$ & .736 & 0 (low TAS) & 10 (high TAS) \\
\hline Self-monitoring & 18 forced binary choice items & $\begin{array}{l}\text { Snyder and Gangestad's } \\
\text { Improved Self-Monitoring } \\
\text { Scale (Snyder and } \\
\text { Gangestad, 1986) }\end{array}$ & .653 & 0 & 18 \\
\hline Loss aversion & Six lotteries (accept or reject) & Gächter et al. (2007) & N.A. & $\begin{array}{l}1 \\
\text { (low loss aversion) }\end{array}$ & $\begin{array}{l}7 \\
\text { (high loss aversion) }\end{array}$ \\
\hline \multirow[t]{2}{*}{ Risk attitude } & \multirow[t]{2}{*}{$\begin{array}{l}\text { Ten choices between paired } \\
\text { lotteries, } \mathrm{A} \text { and } \mathrm{B}\end{array}$} & \multirow{2}{*}{$\begin{array}{l}\text { Low-payoff treatment by } \\
\text { Holt and Laury (2002); } \\
\text { reversed scores }\end{array}$} & \multirow[t]{2}{*}{ N.A. } & 1 (risk averse) & 10 (risk seeking) \\
\hline & & & & \multicolumn{2}{|c|}{ Risk neutrality $=6$} \\
\hline Age & In years & N.A. & N.A. & N.A. & N.A. \\
\hline Female & $1 / 0$ & N.A. & N.A. & 0 & 1 \\
\hline Friends & $1 / 0$ & N.A. & N.A. & 0 & 1 \\
\hline Business_Economics & $1 / 0$ & N.A. & N.A. & 0 & 1 \\
\hline Master_PhD & $1 / 0$ & N.A. & N.A. & 0 & 1 \\
\hline Financial experience & $\begin{array}{l}\text { 9-point Likert score }(1=\text { 'I do } \\
\text { not agree' to 9= 'I fully agree') }\end{array}$ & N.A. & N.A. & 1 & 9 \\
\hline Market size & In number of persons & $\begin{array}{l}\text { Number of subjects in a } \\
\text { market (session) }\end{array}$ & N.A. & N.A. & N.A. \\
\hline
\end{tabular}

${ }^{20}$ For all scales using several items, we established that the measurements are distinct, using confirmatory factor analyses. We ran reliability tests and common factor analyses per scale. Based on the results, we do not exclude any items from the original scales. Risk aversion, loss aversion and all personality variables are mean-centered and standardized at the market (session) level. 
Appendix A2.

Table A2: Differences between sessions and market types

\begin{tabular}{|c|c|c|c|c|c|c|c|c|c|}
\hline \multirow[t]{3}{*}{ Session } & \multirow{3}{*}{$\begin{array}{l}\text { Number } \\
\text { of traders }\end{array}$} & \multirow{2}{*}{\multicolumn{2}{|c|}{$\begin{array}{c}\text { NORM } \\
\text { (T1) }\end{array}$}} & \multirow{2}{*}{\multicolumn{2}{|c|}{$\begin{array}{c}\text { PRE-SHOCK } \\
\text { (T2-PRE) }\end{array}$}} & \multicolumn{4}{|c|}{ POST-SHOCK } \\
\hline & & & & & & \multicolumn{2}{|c|}{$\begin{array}{c}\text { High shock } \\
\text { (T2-POST HI) }\end{array}$} & \multicolumn{2}{|c|}{$\begin{array}{c}\text { Low shock } \\
\text { (T2-POST LO) }\end{array}$} \\
\hline & & \# Trades & Price & \# Trades & Price & \# Trades & Price & \# Trades & Price \\
\hline 1 & 15 & 15.2 & 211.013 & 7.756 & 214.15 & 6.6 & 337.276 & 6.133 & 81.821 \\
\hline 2 & 14 & 15.119 & 128.284 & 7.452 & 125.34 & 4.714 & 296.939 & 6.19 & 91.399 \\
\hline 3 & 13 & 10.051 & 206.205 & 4.256 & 201.845 & 2.769 & 330.939 & 3.487 & 64.189 \\
\hline 4 & 12 & 5.222 & 230.435 & 3.722 & 222.749 & 1.667 & 335.1 & 2.833 & 49.264 \\
\hline 5 & 12 & 8.278 & 202.18 & 5.639 & 202.083 & 2.889 & 344.321 & 3.889 & 55.829 \\
\hline 6 & 14 & 6.69 & 178.591 & 3.786 & 176.771 & 2.476 & 348.449 & 4 & 48.045 \\
\hline 7 & 9 & 10.481 & 187.21 & 6.185 & 185.714 & 3.5 & 331.357 & 5.778 & 50.339 \\
\hline 8 & 12 & 7.333 & 197.705 & 4.778 & 196.826 & 2.556 & 343.437 & 4.944 & 48.05 \\
\hline 9 & 12 & 13.25 & 254.835 & 5.194 & 254.401 & 3.583 & 340.647 & 5.625 & 57.949 \\
\hline 10 & 8 & 10.083 & 155.655 & 5.833 & 151.452 & 4.5 & 264.444 & 6.4 & 58.452 \\
\hline 11 & 10 & 7.733 & 242.132 & 2.933 & 248.081 & 3.1 & 348.359 & 3.75 & 53.297 \\
\hline 12 & 10 & 7.933 & 188.14 & 4 & 190.86 & 3.333 & 328.107 & 2.067 & 58.753 \\
\hline 13 & 10 & 8.333 & 169.129 & 5.1 & 169.029 & 2.8 & 316.136 & 5.75 & 54.589 \\
\hline 14 & 10 & 12.133 & 95.343 & 4.467 & 134.534 & 2.6 & 355.543 & 5.4 & 90.37 \\
\hline 15 & 10 & 5.8 & 179.568 & 4.333 & 164.737 & 2.44 & 338.602 & 4.8 & 59.125 \\
\hline All & $11.4(171)$ & 9.75 & 189.691 & 5.097 & 190.257 & 3.358 & 331.72 & 4.727 & 62.159 \\
\hline \multicolumn{2}{|c|}{ Averages per subject: } & & & & & & & & \\
\hline \multicolumn{2}{|c|}{ Avg. trading frequency } & 9.75 & & 5.097 & & 3.358 & & 4.727 & \\
\hline \multicolumn{2}{|c|}{ Avg. scalping frequency } & 3.395 & & 1.262 & & 0.888 & & 1.016 & \\
\hline \multicolumn{2}{|c|}{ Avg. market price } & 189.691 & & 190.257 & & 331.72 & & 62.159 & \\
\hline
\end{tabular}

